Reprint from
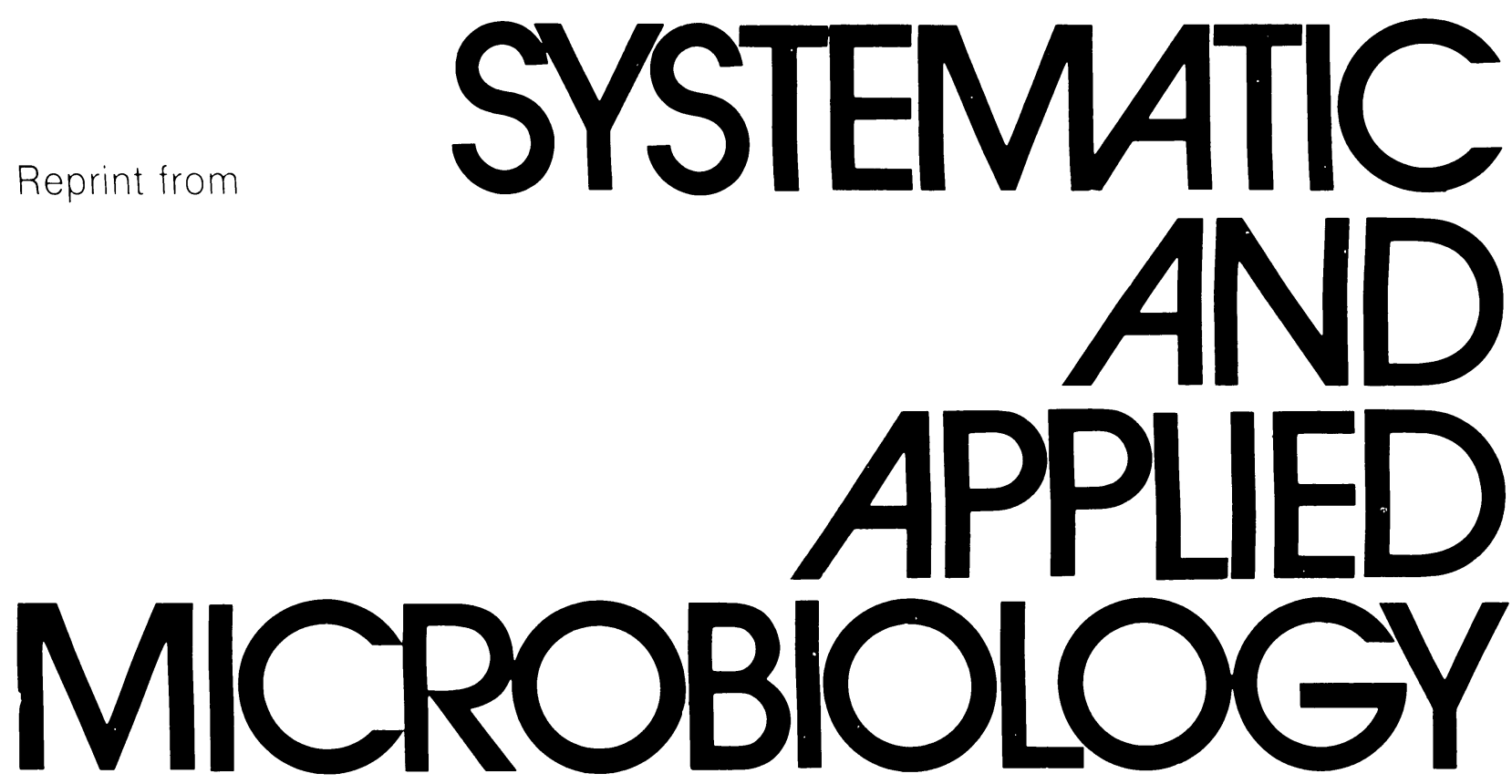

formerly Zentralblatt für Bakteriologie.

Mikrobiologie und Hygiene

I. Abt. Originale C 

Whiting, G. C., Coggins, R. A.: A new nicotinamide-adenine dinucleotide-dependent hydroaromatic dehydrogenase of Lactobacillus plantarum and its role in formation of $(-) t-3, t-4-$ dihydroxycyclohexane-c-1 carboxylate. Biochem. J. 141 , $35-42(1974)$
Woese, C. R., Maniloff, J., Zablen, L. B.: Phylogenetic analysis of the mycoplasmas. Proc. Natl. Acad. Sci. USA 77, 494-498 (1980)

Wood, H. G.: Inorganic pyrophosphate and polyphosphates as sources of energy. Curr. Top. Cell. Regul. 26, 355-369 (1985)

Dr. Paul A. Hartman, Dept. of Microbiology, lowa State University, 205 Science Bldg. I, Ames, IA 50011-3211, USA 


\title{
Localisation of a Region on Subunit B' Neighboring the Active Center of the RNA Polymerase from Methanobacterium thermoautotrophicum Strain W
}

\author{
EVGENY F. ZAYCHIKOV ${ }^{1}$, ARKADIJ A. MUSTAEV ${ }^{1}$, STEPHAN J. GLASER ${ }^{2}$, MICHAEL THOMM ${ }^{3}$, \\ MIKHAIL A. GRACHEV ${ }^{1}$, and GUIDO R. HARTMANN ${ }^{2 *}$ \\ 1 Limnological Institute, Siberian Division of the USSR Academy of Sciences, 664033 Irkutsk, USSR \\ 2 Institut für Biochemie, Ludwig-Maximilians-Universität München, 8000 München 2, Federal Republic of Germany \\ 3 Lehrstuhl für Mikrobiologie, Universität Regensburg, 8400 Regensburg, Federal Republic of Germany
}

Received December 22, 1989

\begin{abstract}
Summary
The immediate neighborhood of the active center of the DNA-directed RNA polymerase from the archaebacterium Methanobacterium thermoautotrophicum is radioactively labeled upon incubation of the enzyme with one of 15 different chemically reactive nucleotide analogs which function as initiating substrate and with $\left[\alpha-{ }^{33} \mathrm{P}\right]$ UTP as elongating substrate in presence of poly $[\mathrm{d}(\mathrm{A}-\mathrm{T})]$ as template. All analogs lead to the labeling of subunit $B^{\prime}$. With analogs containing an alkyl chloride as the chemically reactive group, subunit $\mathrm{B}^{\prime \prime}$ also becomes labeled. This suggests that regions of subunit $\mathrm{B}^{\prime \prime}$ must also be located close to the active center. In the case of subunit $B^{\prime}$ the label is attached between ty $^{273}$ and met $^{383}$. Comparison of the amino acid sequence of the labeled region with that of labeled regions in RNA polymerase from other sources indicates a strong conservation of the active center during evolution.
\end{abstract}

Key words: Archaebacteria - Methanobacterium thermoautotrophicum - RNA polymerase - Active Center - Affinity labeling - Evolution

\section{Introduction}

The binding site of the initiating nucleotide in the active center of the DNA-directed RNA polymerase from archaebacteria can be labeled highly specifically (Thomm et al., 1988) using the method designed by Grachev and Mustaev (1982). This method is based on the reaction sequence

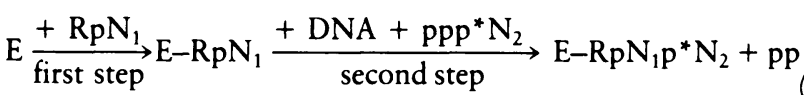

$\left(\mathrm{RpN}_{1}\right.$, chemically reactive analog of the initiating nucleotide; E, DNA-directed RNA polymerase; $\mathrm{ppp}^{*} \mathrm{~N}_{2}[\alpha-$ $\mathrm{P}$ ] radioactively labeled nucleoside triphosphate). In nonmethanogenic, thermophilic archaebacteria, such as Sulfolobus acidocaldarius, the largest subunit designated B becomes radioactively labeled (Thomm et al., 1988). The labeled region of this subunit contains an amino acid sequ-

* Corresponding author ence (Grachev et al., 1989b) which is also found in highly conserved form in the labeled region of subunit $B_{150}$ of RNA polymerase B (II) from Saccharomyces cerevisiae (M. Riva, C. Carles, A. Sentenac, M. A. Grachev, A. A. Mustaev, E. F. Zaychikov, submitted) and in the labeled region of subunit $\beta$ from Escherichia coli (Grachev et al., 1989a). The second and third components, $\mathrm{B}^{\prime}$ and $\mathrm{B}^{\prime \prime}$, of the RNA polymerase from methanogens and extreme halophiles are immunologically related to different parts of subunit B from sulfur-dependent archaebacteria (Schnabel et al., 1983). When RNA polymerases of this type are used as enzyme in the labeling procedure with the 4-hydroxybenzaldehyde ester of ATP as the chemically reactive analog of the initiating nucleotide, subunit $\mathrm{B}^{\prime}$ becomes labeled (Thomm et al., 1988). We were interested in investigating whether the labeling of subunit $\mathrm{B}^{\prime}$ depends on the exact chemical structure of the analog of the initiating substrate. Furthermore, we wanted to localize the region of subunit 
$\mathrm{B}^{\prime}$ to which the radioactive label becomes attached. As the amino acid sequence of subunit $B^{\prime}$ of this enzyme is known (Berghöfer et al., 1988), the mapping of the attachment site can be carried out by the method developed by Grachev et al. (1989a).

\section{Materials and Methods}

RNA polymerase from Methanobacterium thermoautotrophicum strain W was purified as described (Thomm et al., 1986) and the preparation divided into $15 \mu \mathrm{l}$ aliquots, sealed under $\mathrm{N}_{2} /$ $\mathrm{H}_{2}(95: 5)$ and stored in liquid nitrogen.

Synthesis of the reactive adenine nucleotide analogs. Analogs I to VI were synthesized similarly as described for the GMP analog by Grachev et al., 1989a (see also Grachev et al., 1986) with the triethylammonium salts of the corresponding adenine nucleotides. Similarly, analog VII was synthesized from ATP and vanilline (Grachev et al., 1987b). The synthesis of VIII and of the imidazolides X and XI is described by Grachev et al. (1987a). The same procedure is applied for the synthesis of the ATP derivative IX. XIII is synthesized as XII (Grachev et al., 1987a).

Synthesis of analog XIV. $5 \mu \mathrm{l} \mathrm{N}$-methylimidazole, $15 \mathrm{mg}$ triphenylphosphine and $15 \mathrm{mg} 2,2^{\prime}$-dipyridyldisulfide were added to $5 \mathrm{mg}$ AMP (triethylammonium salt) dissolved in $50 \mu \mathrm{l} \mathrm{di-}$ methylsulfoxide and the mixture incubated for $10 \mathrm{~min}$ at room temperature. Then $10 \mathrm{mg}$ methyl-2-chloroethylamine hydrochloride and an equimolar quantity of triethylamine were added and the incubation continued for $10 \mathrm{~min}$. The product was precipitated with $1 \mathrm{ml}$ ether and washed several times with ether until the yellow color had disappeared. XIV was purified by thin layer chromatography on silica gel $60 \mathrm{~F}_{254}$ plates (Merck, Darmstadt), with acetonitrile/water $(4: 1)$ as solvent $\left(R_{F}: 0.33\right)$. The purified compound is homogeneous as judged by thin-layer chromatography on silica gel $60 \mathrm{~F}_{254}$ plates with dioxane/concentrated ammonia/water $(6: 4: 1)$ as solvent as well as by microcolumn liquid chromatography on DEAE-cellulose (Baram et al., 1983). The latter procedure indicates -1 as the charge of the compound. The UV spectrum is identical to that of AMP. Treatment with $0.01 \mathrm{M} \mathrm{HCl}$ at $37^{\circ} \mathrm{C}$ for $10 \mathrm{~h}$ produces AMP (charge -2 as revealed by microcolumn chromatography) and the corresponding amine.

Synthesis of analog XV. $10 \mathrm{mg}$ ATP (triethylammonium salt) was dissolved in $60 \mu \mathrm{l}$ dimethylformamide, mixed with $10 \mathrm{mg} \mathrm{4-}$ formylbenzylbromide and $5 \mu$ liisopropylethylamine and heated at $60^{\circ} \mathrm{C}$ for $15 \mathrm{~min}$. The product was precipitated with $1 \mathrm{ml}$ acetone containing $1 \% \mathrm{Nal}$, washed with acetone and purified by chromatography on silica gel $60 \mathrm{~F}_{254}$ thin layer plates with acetonitrile/water $(4: 1)$ as solvent $\left(\mathrm{R}_{\mathrm{F}}: 0.25\right)$. It gave an orange color upon staining with 2,4-dinitrophenylhydrazine. The compound was eluted with water and dried in vacuo. It is homogeneous as judged by thin layer chromatography described for analog XIV. The mobility is not altered after treatment with alkaline phosphatase. Microcolumn liquid chromatography on DEAEcellulose indicates a charge of -3 of the product (Baram et al., 1983). Its UV spectrum exhibits a maximum at $258 \mathrm{~nm}$ and a minimum at $229 \mathrm{~nm}\left(\mathrm{~A}_{290} / \mathrm{A}_{258}=0.12\right)$. After reduction with $0.05 \mathrm{M}$ borohydride $\left(5 \mathrm{~min}\right.$ at $20^{\circ} \mathrm{C}$ ) the spectrum changed to a maximum at $262 \mathrm{~nm}$, and a minimum at $235 \mathrm{~nm}$.

Affinity labeling. The reaction mixture contained $20 \mathrm{mM}$ HEPES, pH 7.9, $10 \mathrm{mM} \mathrm{MgCl}, 0.1 \mathrm{M} \mathrm{KCl}, 0.1-0.3 \mathrm{mg} / \mathrm{ml} \mathrm{RNA}$ polymerase (from a freshly opened vial) and $1 \mathrm{mM}$ nucleotide analog except for III $(2.5 \mathrm{mM})$ and XII or ATP $(0.5 \mathrm{mM})$. The mixture was incubated for $15 \mathrm{~min}$ at $37^{\circ} \mathrm{C}$. Sodium borohydride (up to $10 \mathrm{mM}$ ) was then added and the mixture incubated for another $15 \mathrm{~min}$ at $0^{\circ} \mathrm{C}$. In some experiments analogs XII and XIII were first reduced by treatment with borohydride $(5 \mathrm{mM}$ reagent, $50 \mathrm{mM} \mathrm{NaBH}_{4}, 5 \mathrm{~min}, 20^{\circ} \mathrm{C}$ ) and then immediately incubated with RNA polymerase for $30 \mathrm{~min}$ at $37^{\circ} \mathrm{C}$ followed by elongation. With IX-XI and XIV the reduction step was omitted. Here the time of incubation was $30 \mathrm{~min}$ at $37^{\circ} \mathrm{C}$. For the elongation step $0.1 \mathrm{mg} / \mathrm{ml}$ poly[d(A-T)] (Sigma) and approximately, $1 \mathrm{mCi} /$ $\mathrm{ml}\left[\alpha-{ }^{33} \mathrm{P}\right]$ UTP (Isotop, Tashkent, $2000 \mathrm{Ci} / \mathrm{mmole}$ ) were added and the incubation continued for $30 \mathrm{~min}$ at $56{ }^{\circ} \mathrm{C}$. ${ }^{33} \mathrm{P}$ labeled material was used as it yields sharper bands in the autoradiography due to the much lower radiation energy. Then $0.25 \mathrm{mg} / \mathrm{ml}$ RNase A (Serva, Heidelberg) was added and the incubation continued for $30-45 \mathrm{~min}$ at $37^{\circ} \mathrm{C}$.

Electrophoretic analysis. The mixture was heated for $15 \mathrm{~min}$ at $56^{\circ} \mathrm{C}$ in presence of $1 \%$ SDS and $1 \%$ mercaptoethanol and subjected to electrophoresis in a polyacrylamide gradient $(10-25 \%)$ slab gel $(13 \times 18 \times 0.05 \mathrm{~cm})$ in presence of $0.1 \%$ SDS. For the isolation of the separated labeled polypeptides the piece of gel containing the polypeptide was cut out, washed with $0.5 \mathrm{ml}$ water for $2 \mathrm{~min}$, then crushed and eluted two times in $0.2 \mathrm{ml}$ water containing $0.1 \%$ SDS and $50 \mu \mathrm{g} / \mathrm{ml}$ bovine serum albumine for $15 \mathrm{~min}$. The eluates were combined, freeze-dried and dissolved in water.

Cleavage of the labeled enzyme. After RNase treatment SDS was added to $1 \%$ of the reaction mixture and the incubation continued for $30 \mathrm{~min}$ at $37^{\circ} \mathrm{C}$ or $15 \mathrm{~min}$ at $56^{\circ} \mathrm{C}$.

Limited cleavage with $\mathrm{H}_{2} \mathrm{NOH}$ was carried out as described (Grachev et al., 1989b). The control was performed identically but without $\mathrm{H}_{2} \mathrm{NOH}$ ( $2.5 \mathrm{~h}$ incubation).

Limited and long time ( $22 \mathrm{~h}$ ) cleavage with $\mathrm{BrCN}$ was carried out as described (Grachev et al., 1989b). For the control the labeled enzyme was also incubated at $\mathrm{pH} \mathrm{1-2} \mathrm{but} \mathrm{without} \mathrm{addi-}$ tion of $\mathrm{BrCN}$. Here the incubation period was identical with that of the longest incubation with $\mathrm{BrCN}$. Under the acid conditions cleavage at asp-pro bonds $(55 / 56 ; 127 / 128)$ may occur.

Cleavage with bromine-water was carried out similarly as described (Maximova et al., 1989). The solution of the isolated $\mathrm{BrCN}$ fragment from the $\mathrm{B}^{\prime}$ subunit was acidified with $\mathrm{HCl}$ to $\mathrm{pH}$ $1-2$ and $1 / 8$ volume of a $1: 10$ diluted saturated solution of bromine in water was added. After $5 \mathrm{~min}$ incubation at room temperature, the cleavage was stopped by addition of $1 / 4$ volume of a solution containing $5 \%$ mercaptoethanol, $0.5 \mathrm{M}$ triethanolamine, $\mathrm{pH} 9,0.2 \%$ bromophenol blue, $50 \%$ glycerol. The control was treated identically but without bromine-water. A gel gradient containing $20-30 \%$ acrylamide was used for electrophoretic analysis in this experiment.

\section{Results}

\section{Influence of the substrate analog}

The highly specific labeling of the RNA polymerase from Methanobacterium thermoautotrophicum strain W was carried out with a large variety of chemically reactive analogs of the initiating nucleotide (Table 1 ) in presence of poly $[\mathrm{d}(\mathrm{A}-\mathrm{T})]$ as template and $\left[\alpha-{ }^{33} \mathrm{P}\right] \mathrm{UTP}$ as second substrate. These analogs differed from each other in the distance of the chemically reactive group from the nucleoside monophosphate moiety or in the nature of the chemically reactive group (either an aldehyde, imidazole or alkylchloride group). Two of them (XII and XIII) were bifunctional since they carried two different reactive groups. With all derivatives at least a weak labeling of the second largest subunit B' was achieved similar to that shown pre- 
Table 1 . Chemically reactive nucleotide analogs used in the highly specific labeling procedure

\begin{tabular}{|c|c|}
\hline SUBSTRATE ANALOG & ABBREVIATION \\
\hline${ }_{C H O}-\left[P 0_{3}\right]_{N}-5 '-A D O$ & $I: N=3 ; I I: N=2 ; I I I: N=1$ \\
\hline$O H C-\left(1-0-\left(P 0_{3}\right)_{N}-5_{1}-A D O\right.$ & IV: $N=3 ; V: N=2 ; V I: N=1$ \\
\hline $\left.\mathrm{OHC}-\mathrm{OCH}_{3} \mathrm{O}-\mathrm{PO}_{3}\right]_{3}-5^{\prime}-\mathrm{ADO}$ & VII \\
\hline $\mathrm{OHC}-\mathrm{N}\left(\mathrm{CH}_{3}\right)-\left(\mathrm{CH}_{2}\right)_{2}-0-\left(\mathrm{PO}_{3}\right)_{3}-5^{\prime}-\mathrm{ADO}$ & VIIII \\
\hline$\underbrace{\widehat{N} N-(P 03]_{N}-5^{\prime}-A D O}$ & $I X: N=3 ; X: N=2 ; X I: N=1$ \\
\hline $\mathrm{OHC}-\left[\mathrm{N}\left(\mathrm{CH}_{2}-\mathrm{CH}_{2} \mathrm{Cl}\right)-\left(\mathrm{CH}_{2}\right) 2-0-\left[\mathrm{PO}_{3}\right]_{\mathrm{N}}-5^{\prime}-\mathrm{ADO}\right.$ & $X I I: N=3 ; X I I I: N=1$ \\
\hline $\mathrm{CL}-\mathrm{CH}_{2}-\mathrm{CH}_{2}-\mathrm{N}\left(\mathrm{CH}_{3}\right)-\left(\mathrm{PO}_{3}\right)-5^{\prime}-\mathrm{ADO}$ & XIV \\
\hline $\mathrm{OHC}-\mathrm{CH}_{2}-\mathrm{O}-\left(\mathrm{PO}_{3}\right)_{3}-5^{\prime}-\mathrm{ADO}$ & $x v$ \\
\hline
\end{tabular}

viously (Thomm et al., 1988) with analog IV (data not shown). However, with analog XIV which carries an alkylating group, the third largest subunit $\mathrm{B}^{\prime \prime}$ in addition to $\mathrm{B}^{\prime}$ became labeled (Fig. 1; A).

The labelling of subunit $\mathrm{B}^{\prime \prime}$ is dependent on the presence of template and substrate analog and disappears after incubation with proteinase $\mathrm{K}$ (Fig. 1; B, C, D). The same has been observed in all previous labeling experiments using this method (Hartmann et al., 1988). A strong labeling of subunit $\mathrm{B}^{\prime \prime}$ is also observed when the reduced form of analogs XII and XIII (obtained by $\mathrm{NaBH}_{4}$ reduction of the aldehyde group with concomitant activation of the alkylating activity of the ethylchloride group) is incubated with the enzyme (Fig. 1; E, G). When the aldehyde group of XII and XIII is not reduced prior to the reaction with the enzyme the labeling of subunit $B^{\prime}$ is increased and that of $B^{\prime \prime}$ strongly decreased (Fig. $1 ; \mathrm{F}, \mathrm{H}$.). It suggests that the labeling of subunit $B^{\prime \prime}$ is mainly due to alkylation whereas subunit $\mathrm{B}^{\prime}$ is available to both the ethylchloride and to the aldehyde group of the affinity reagents.

\section{Mapping of the attachment site for analog III}

When substrate analog III is used in the labeling procedure, exclusively subunit B' consisting of 604 amino acids
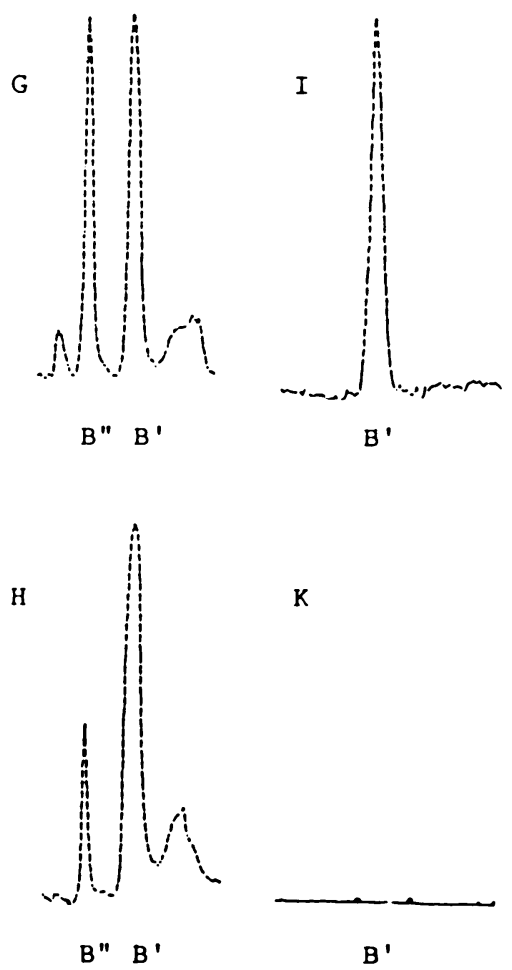

Fig. 1. Affinity labeling of Methanobacterium thermoautotrophicum RNA polymerase with different nucleotide analogs. The densitometric tracing of the autoradiographies of the gel electrophoretic analyses is shown. B' and B" indicate the position of the subunits. A-D: alkylating analog XIV; A: complete; B: without template; C: without analog; D: complete with subsequent 15 min digestion by proteinase K (Merck, Darmstadt); E, F: bifunctional analog XII, borohydride reduction before or after incubation with the enzyme. G, $\mathrm{H}$ : bifunctional analog XIII, reduction before or after incubation with the enzyme. I: analog III, complete with reduction by $\mathrm{NaBH}_{4} ; \mathrm{K}$ : complete without analog but with $1 \mathrm{mM}$ ATP. 
Fig. 2. Scheme A. Position of met residues and asn-gly peptide bonds in the amino acid sequence of subunit $\mathrm{B}^{\prime}$ from $M$. thermoautotrophicum (Berghöfer et al., 1988). Met-ser (at $112,211,405)$ and met-thr $(156,482)$ have been omitted for clarity.

Scheme B. Position of tyr between glu 219 and met 383 . Position of lys between tyr 273 and met 383 .

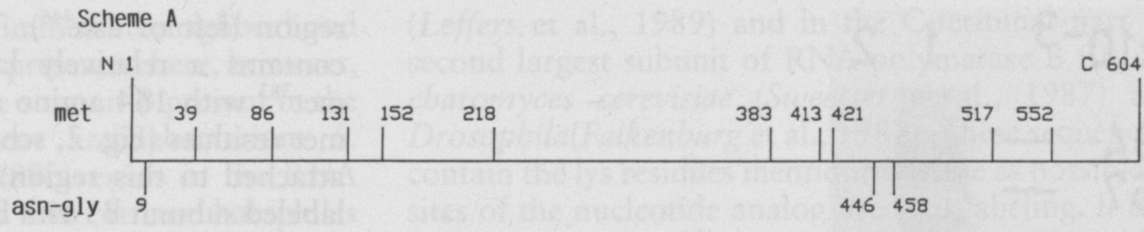

Scheme B

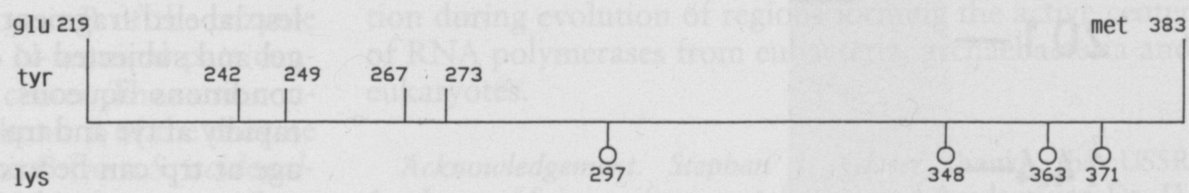

$\left(M_{r} 68000\right)$, becomes labeld (Fig. 1; I, K). The polypeptide contains three asn-gly bonds (at the asn positions 9, 446 and 458; Fig. 2, scheme A) (Berghöfer et al., 1988). They may be cleaved rather specifically by hydroxylamine at $\mathrm{pH}$ 10 (Bornstein et al., 1977) yielding two large polypeptides with $\mathrm{M}_{\mathrm{r}} 51000$ and 52000 and two small polypeptides with 18000 and 17000 . Indeed, a limited cleavage leads to the appearance of two adjacent labeled bands with $\mathrm{M}_{\mathrm{r}}$, app of approximately 52000 and 55000 (Fig. 3, lane 2) in addition to the radioactive zones already present in the control (Fig. 3; lane 1). No radioactive bands with $\mathrm{M}_{\mathrm{r}}$, app between 17000 and 18000 can be seen (corresponding to the fragments gly $^{447}$ or ${ }^{459}$-C-terminus ${ }^{604}$ ). This clearly demonstrates that the label must be attached to the region left of $\operatorname{asn}^{446}$ (see scheme A).

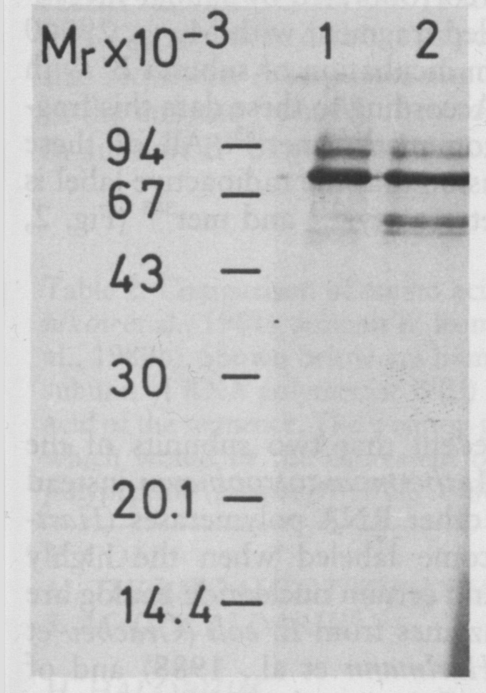

Fig. 3. Limited cleavage of labeled M. thermoautotrophicum RNA polymerase with $\mathrm{H}_{2} \mathrm{NOH}$ (lane 2). Control (lane 1): incubation in absence of $\mathrm{H}_{2} \mathrm{NOH}$.
BrCN cleaves polypeptides rapidly at met residues except when they are followed by thr and ser (Schroeder et al., 1969). Following incubation of the labeled enzyme with $\mathrm{BrCN}$ under conditions where only a small part of subunit $\mathrm{B}^{\prime}$ is cleaved (single hit conditions: in the average less than one cleavage per polypeptide chain (Grachev et al., 1989a), several labeled fragments appear in addition to those present in the control (Fig. 4, lanes 1-4). The smallest fragment formed has a size of about 45000 . Subunit $\mathrm{B}^{\prime}$ contains 10 met residues not followed by thr or ser which are distributed rather evenly over the polypeptide chain, particularly over the $\mathrm{N}$ - and C-terminal region (Fig. 2 , scheme A). The absence of products smaller than 45000 is evidence that the radioactive label is not attached to the two terminal regions but must be located in the middle

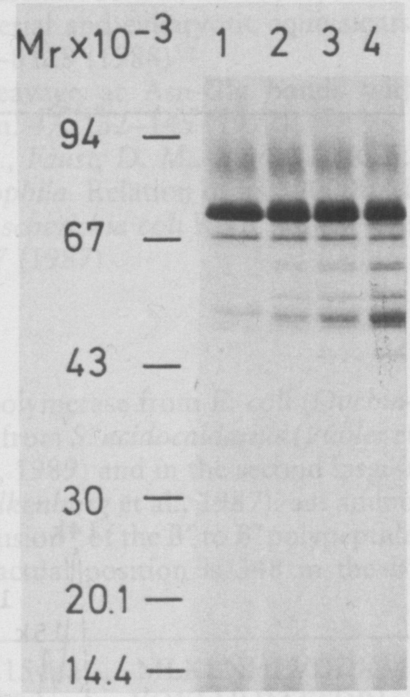

Fig. 4. Limited cleavage of labeled M. thermoautotrophicum RNA polymerase with $\mathrm{BrCN}$. Lane 1: control, lanes 2, 3, 4: 1, 2 and 5 min incubation with $\mathrm{BrCN}$, respectively. The formation of the labeled bands with $\mathrm{M}_{\mathrm{r}}$, app 63000 and 55000 in the control is due to cleavage at the asp-pro bonds at positions 55 and 127 under the prevailing acid conditions. 


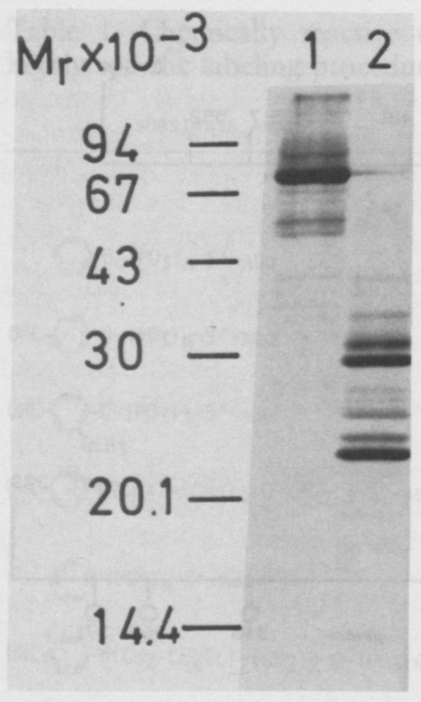

Fig. 5. Long term cleavage of labeled M. thermoautotrophicum RNA polymerase with $\mathrm{BrCN}$. $22 \mathrm{~h}$ incubation without (lane 1) and with (lane 2) $\mathrm{BrCN}$.
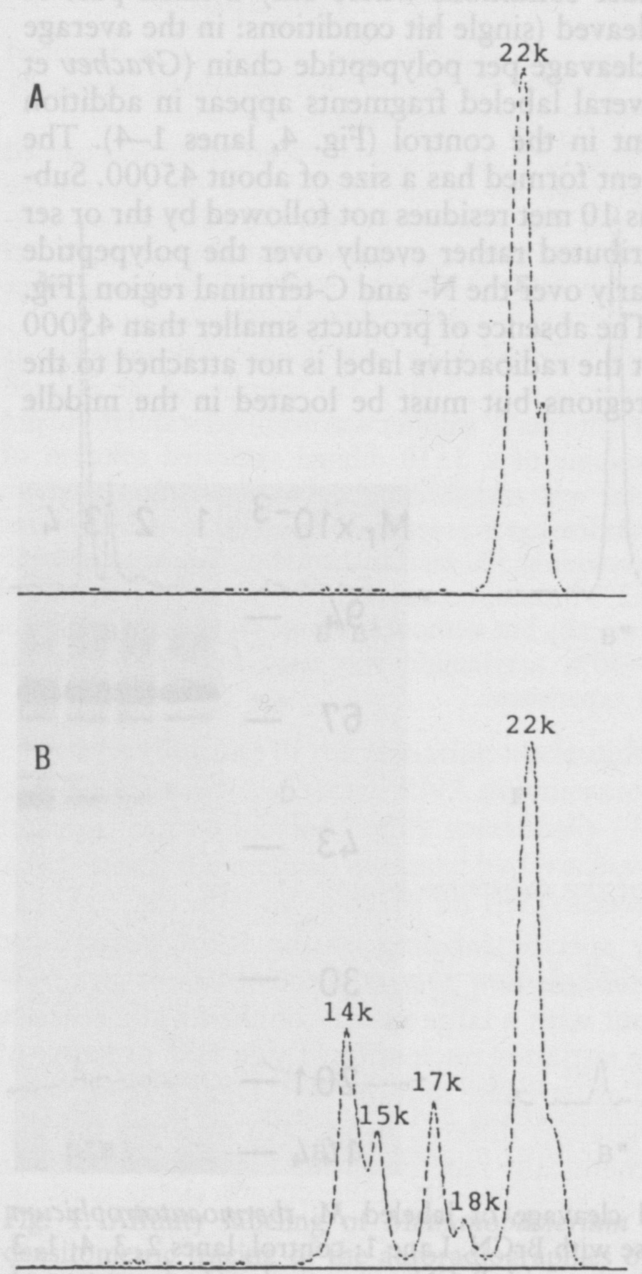

Fig. 6. Limited cleavage by bromine of the labeled 22000 fragment obtained after the long time incubation of the labeled enzyme with BrCN. A: control B: 5 min incubation. region (left of $\left.a n^{446}\right)$. The middle region of subunit $\mathrm{B}^{\prime}$ contains a relatively large region between $\mathrm{met}^{218}$ and met ${ }^{383}$ with 164 amino acids $\left(M_{r} 18700\right)$ which is free of met residues (Fig. 2, scheme A). If the label $\left(M_{r} \sim 800\right)$ is attached to this region, a longer incubation time of the labeled subunit $\mathrm{B}^{\prime}$ with $\mathrm{BrCN}$ leading to the disappearance of the intact subunit should result in the formation of radioactive products equal to or larger than 19500 . Indeed, this is observed (Fig. 5, lane 1,2). Most of the radioactivity is found in fragments with $\mathrm{M}_{\mathrm{r}}$, app 22000 and 29000.

To locate the attachment site more precisely, the smallest labeled fragment $\left(M_{r}\right.$, app 22000$)$ was eluted from the gel and subjected to cleavage with bromine. Under acidic conditions aqueous bromine cleaves polypeptides most rapidly at tyr and trp residues (Spande et al., 1970). Cleavage at trp can be excluded here since subunit $\mathrm{B}^{\prime}$ contains only one trp residue (at position 88) far away from the middle region. At a low concentration of bromine, only a limited cleavage occurs (condition of single hit, Grachev et al., 1989a) since the main part of the BrCN fragment present remains intact (Fig. 6). Four degradation products with different intensities and characteristic mobilities can be detected $\left(\mathrm{M}_{\mathrm{r}}\right.$, app $\left.18000,17000,15000,14000\right)$. None is smaller than 14000 . This suggests that the label is attached to a region of that size which is free of tyr. There exists only one region of this size bordered by either tyr only or tyr and met in the middle part of subunit $\mathrm{B}^{\prime}$ which fulfills these conditions. This is the region between $\operatorname{tyr}^{273}$ and $\mathrm{met}^{383}$ (scheme B). Since three more tyr residues (at positions $267,249,242$ ) occur before the next met residue at position 218, a single hit cleavage (Grachev et al., 1989 a), by bromine at these residues should result in the formation of three additional radioactive fragments with the size of 14000,16000 and 17000 . This characteristic pattern of radioactive fragments was observed (Fig. 6). Cleavage at $\operatorname{tyr}^{242}$ seems to be the rarest since the intensity of this product is the smallest.

These observations are corroborated by similar investigations of the eluted labeled fragment with $\mathrm{M}_{\mathrm{r}}$, app 29000 obtained after a long term incubation of subunit $\mathrm{B}^{\prime}$ with $\mathrm{BrCN}$ (data not shown). According to these data this fragment comprises the region $\operatorname{met}^{152}-$ met $^{383}$. All of these results support the conclusion that the radioactive label is attached to the region between $\operatorname{tyr}^{273}$ and met $^{383}$ (Fig. 2, scheme B).

\section{Discussion}

It is not without precedent that two subunits of the RNA polymerase from M. thermoautotrophicum instead of only one, as in many other RNA polymerases (Hartmann et al., 1988), become labeled when the highly specific labeling method and certain nucleotide analog are applied. In case of the enzymes from E. coli (Grachev et al., 1987a), Anabaena (Hartmann et al., 1988) and of DNA primase from yeast (Foiani et al., 1988), two subunits (beta and sigma or the primase subunits p48 and p58, respectively) also become labeled. This suggests that 
more than one subunit forms the immediate neighborhood of the active center. The example presented here, however, is of particular interest. The large subunit $B$ present in the enzyme of the sulfur dependent archaebacterium $S$. acidocaldarius (Pübler et al., 1989b) exists in the RNA polymerases of the methanogens and extreme halophiles in a split form. The two subunits B" and B' are homologous in sequence to the $\mathrm{N}$-terminal and $\mathrm{C}$-terminal part of subunit B, respectively (Berghöfer et al., 1988; Leffers et al., 1989). Labeling of both subunits $B^{\prime \prime}$ and $B^{\prime}$ indicates that regions of these two polypeptides are very close to the active center in the three-dimensional structure. Perhaps not only the C-terminal part of subunit B of the enzyme from $S$. acidocaldarius but also the N-terminal part contains regions neighboring the active center. The same concept may be applied similarly to subunit $\beta$ of the enzyme from $E$. coli which resembles subunit B from $S$. acidocaldarius in sequence (Pübler et al., 1989a).

In the case of the enzyme from E. coli (Ovchinnikov et al., 1981), the label becomes attached to either one of two regions (ile ${ }^{1036}-$ met $^{1066}$ or met $^{1232}-$ met $^{1243}$ ) (Grachev et al., 1989a) of subunit $\beta$. In subunit B from $S$. acidocaldarius the label is bound to the region between gly ${ }^{843}$ and met $^{895}$ (Grachev et al., 1989b) whereas in subunit $\mathrm{B}^{\prime}$ of the enzyme from $M$. thermoautotrophicum the label is fixed to the region between $\operatorname{tyr}^{273}$ and met $^{383}$. The attachment site of a nucleotide analog with an aldehyde group is most probably a lys residue (Grachev et al., 1987a). In the labeled region four lys residues occur at the position 297 , 348,363 and 371 . Comparison of the amino acid sequences of this labeled region with the labeled region of subunit B of the enzyme from S. acidocaldarius (Grachev et al., 1989b) and of subunit $\beta$ from E. coli (Grachev et al., 1989a) immediately reveals several regions with high sequence similarity. Particularly striking is a stretch of 16 amino acids in which in $S$. acidocaldarius only a single ser residue is replaced by thr. Even in the less closely related $E$. coli enzyme only six amino acids are replaced by rather conservative substitutions (Table 2). The lys residues 363 and 371 mentioned above as possible targets are present in this sequence. A sequence almost identical to that labeled in the enzyme from $M$. thermoautotrophicum also occurs in subunit $\mathrm{B}^{\prime}$ of the enzyme of Halobacterium halobium
(Leffers et al., 1989) and in the C-terminal part of the second largest subunit of RNA polymerase B (II) of Saccharomyces cerevisiae (Sweetser et al., 1987) and of Drosophila(Falkenburg et al., 1987). These sequences also contain the lys residues mentioned above as possible target sites of the nucleotide analog used for labeling. It did not escape our notice that a sequence of 12 amino acids very similar to that of the second labeled region in the $\beta$ subunit of $E$. coli $\left(\operatorname{met}^{1232}-\operatorname{met}^{1243}\right.$ ) (Table 2) occurs at the same distance (101 or 100 amino acids) in the other polymerases. Only in $E$. coli is this distance increased to 154 amino acids. These findings point to the strong conservation during evolution of regions forming the active center of RNA polymerases from eubacteria, archaebacteria and eukaryotes.

Acknowledgement. Stephan J. Glaser thanks the USSR Academy of Sciences for a travel grant and Academician Dr. D. G. Knorre, Novosibirsk Institute of Bioorganic Chemistry, and the members of the Limnological Institute for their hospitality. Stephan J. Glaser and Guido R. Hartmann gratefully acknowledge the financial help of the Fonds der Chemischen Industrie. The research of Michael Thomm, Stephan J. Glaser and Guido R. Hartmann was supported by the Deutsche Forschungsgemeinschaft.

\section{References}

Baram, G. I., Grachev, M. A., Komarova, N. I., Perelroyzen, M. P., Bolvanov, Yu. A., Kuzmin, S. V., Kargaltsev, V. V., Kuper, E. A.: Micro-column liquid chromatography with multi-wavelength photometric detection I. The OB-4 micro-column liquid chromatograph. J. Chromatogr. 264, 69-90 (1983)

Berghöfer, B., Kröckel, L., Körtner, C., Truss, M., Schallenberg, J., Klein, A.: Relatedness of archaebacterial RNA polymerase core subunits to their eubacterial and eukaryotic equivalents. Nucleic Acids Res. 16, 8113-8128 (1988)

Bornstein, P., Balian, G.: Cleavage at Asn-Gly bonds with hydroxylamine. Meth. Enzym. 47, 132-145 (1977)

Falkenburg, D. Dworniczak, B., Faust, D. M., Bautz, E. K. F.: RNA Polymerase II of Drosophila. Relation of its $140000 \mathrm{M}_{\mathrm{r}}$ subunit to the $\beta$ subunit of Escherichia coli RNA polymerase. J. Molec. Biol. 195, 929-937 (1987)

Table 2. Comparison of amino acid sequences within the labeled regions of the $\beta$-subunit of RNA polymerase from E. coli (Ovchinnikov et al., 1981), subunit B' from M. thermoautotrophicum (Berghöfer et al., 1988) and subunit B from S. acidocaldarius (Pühler et al., 1989b). Shown below are homologous sequences in subunit $\mathrm{B}^{\prime}$ from $H$. halobium (Leffers et al., 1989) and in the second largest subunit of RNA polymerase B (II) from S. cerevisiae (Sweetser et al., 1987) and D melanogaster (Falkenburg et al., 1987). aa: amino acid of the sequence. The position given for M. thermoautotrophicum is for an artifical head to tail "fusion" of the B' to B" polypeptide which would be the equivalent of the subunit in organisms with an uncleaved B subunit. The actual position is 348 in the $B^{\prime}$ polypeptide (Berghöfer et al., 1988).

\section{E. COLI}

M. THERMOAUTOTROPHICUM

S. ACIDOCALDARIUS

H. HALOBIUM

S. CEREVISIAE II

DROSOPHILA MELANOGASTER II
(1051) KVYLAVKRRIQ-PGDKMAGRHGNKGVIS ... 154aa ... MLKLNHLVDDKM

(863) KIRVREQRQPEFIGDKFASRHGQKGVVG ... 100aa ... YQKLHHMTTDRI

(861) KVRVRDLRIPE-IGDKFATRHGQKGVVG ... 101aa ... YQKLHHMVADKM

(875) KVSVRDERIPE-LGDKFASRHGQKGVVG ... 100aa ... YHKL YHMVSNKL

(965) KVRVRTTKIPQ-IGDKFASRHGQKGTIG ... 100aa ... YQRLRHMVDDKI

(869) KIRVRSVRIPQ-IGDKFASRHGQKGTCG ... 100aa ... YQRLKHMVDDKI 
Foiani, M., Lindner, A. J., Hartmann, G. R., Lucchini, G., Plevani, $P .:$ Affinity labeling of the active center and ribonucleoside triphosphate binding site of yeast DNA primase. J. Biol. Chem. 264, 2189-2194 (1989)

Grachev, M. A., Mustaev, A. A.: Cyclic adenosine-5'trimetaphosphate phosphorylates a histine residue nearby the initiating substrate binding site of Escherichia coli DNAdependent RNA-polymerase. FEBS Lett. 137, 89-94 (1982)

Grachev, M. A., Lukhtanov, E. A., Mustaev, A. A.: Synthesis of derivatives of nucleoside $5^{\prime}$-mono-, di-, and triphosphates with reactive groups attached to phosphate residues. Bioorg. Khim. 12, 1079-1087 (1986)

Grachev, M. A., Kolocheva, T. I., Lukhtanov, E. A., Mustaev, A. A.: Studies on the functional topography of Escherichia coli RNA polymerase - Highly selective affinity labelling by analogue of initiating substrates. Eur. J. Biochem. 163, 113-121 (1987a)

Grachev, M. A., Zaychikov, E. F., Lukhtanov, E. A., Maximova, T. G., Mustaev, A. A.: Highly selective affinity labelling of T7 phage RNA polymerase. Bioorg. Khim. 13, 568-570 (1987b)

Grachev, M. A., Lukbtanov, E. A., Mustaev, A. A., Zaychikov, E. F., Abdukayumov, M. N., Rabinov, I. V., Richter, V. I., Skoblov, Yu. S., Chistyakov, P. G.: Studies of the functional topography of Escherichia coli RNA polymerase. - A method for localization of the sites of affinity labelling. Eur. J. Biochem. 180, 577-585 (1989a)

Grachev, M. A., Mustaev, A. A., Zaychikov, E. F., Lindner, A. J. Hartmann, G. R.: Localisation of the binding site for the initiating substrate on the RNA polymerase from Sulfolobus acidocaldarius. FEBS Lett. 250, 317-322 (1989b)

Hartmann, G. R., Biebricher, C., Glaser, S. J., Grosse, F., Katzameyer, M. J., Lindner, A. J., Mosig, H., Nasheuer, H.-P., Rothman-Denes, L. B., Schäffner, A. R., Schneider, G. J., Stetter, K.-O., Thomm, M.: Initiation of transcription - a general tool for affinity labeling of RNA polymerases by autocatalysis. Biol. Chem. Hoppe-Seyler 369, 775-788 (1988)

Leffers, H., Gropp, F., Lottspeich, F., Zillig, W., Garrett, R. A.: Sequence, organization, transcription and evolution of RNA polymerase subunit genes from the archaebacterial extreme halophiles Halobacterium halobium and Halococcus morrhuae. J. Molec. Biol. 206, 1-17 (1989)

Maximova, T. G., Mustaev, A. A., Zaychikov, E. F., Baranova, L. V., Kumarev, V. P., Lukhtanov, E. A.: Localisation of lysine residue nearby the site of initiating substrate binding of $\mathrm{T} 7$ bacteriophage RNA polymerase. Bioorg. Khim. 15, 18-23 (1989)

Ovchinnikov, Yu. A., Monastyrskaya, G. S., Gubanov, V. V., Guryev, S. O., Chertov, O. Yu., Modyanov, N. N., Grinkevich, V. A., Makarova, I. A., Marchenko, T. V., Polounikova, I. N., Lipkin, V. M., Sverdlov, E. D.: The primary structure of Escherichia coli RNA polymerase. Eur. J. Biochem. 116, 621-629 (1981)

Pübler, G., Leffers, H., Gropp, F., Palm, P., Klenk, H.-P., Lottspeich, F., Garrett, R. A., Zillig, W.: Archaebacterial DNAdependent RNA polymerases testify to the evolution of the eukaryotic nuclear genome. Proc. Natl. Acad. Sci. USA 86, 4569-4573 (1989a)

Pühler, G., Lottspeich, F., Zillig, W.: Organization and nucleotide sequence of the genes encoding the large subunits $\mathrm{A}, \mathrm{B}$ and $C$ of the DNA-dependent RNA polymerase of the archaebacterium Sulfolobus acidocaldarius. Nucleic Acids Res. 17, 4517-4534 (1989b)

Schroeder, W. A., Shelton, J. B., Shelton, J. R.: An examination of conditions for the cleavage of polypeptide chains with cyanogen bromide: application to catalase. Arch. Biophys. Biochem. 130, 551-556 (1969)

Schnabel, R., Thomm, M., Gerardy-Schahn, R., Zillig, W., Stetter, K. O., Huet, J.: Structural homology between different archaebacterial DNA-dependent RNA polymerases analyzed by immunological comparison of their components. EMBO J. 2, 751-755 (1983)

Spande, T. F., Witkop, B., Degani, Y., Patchornik, A.: Selective cleavage and modification of peptides and proteins. Advan. Protein Chem. 24, 97-260 (1970)

Sweetser, D., Nonet, M., Young, R. A.: Prokaryotic and eukaryotic RNA polymerases have homologous core subunits. Proc. Natl. Acad. Sci. USA 84, 1192-1196 (1987)

Thomm, M., Madon, J., Stetter, K. O.: DNA-dependent RNA polymerases of the three orders of methanogens. Biol. Chem. Hoppe-Seyler 367, 473-481 (1986)

Thomm, M., Lindner, A. J., Hartmann, G. R., Stetter, K. O.: Affinity labelling of the active center of DNA-dependent RNA polymerases within the archaebacterial kingdom. System. Appl. Microbiol. 10, 101-105 (1988) 